\title{
Effect of an Educational Program on the Nurses' Performance and Health Outcomes for Patients with Traumatic Head Injury
}

\author{
Esraa Hamdy Hassan Ali ${ }^{1}$, Manal Salah Hassan², Hanan Gaber Mohamed ${ }^{3}$, Nehal Mahmoud \\ Abo EL-Fadl ${ }^{4}$
}

(1) Assistant lecturer of Medical Surgical Nursing, Faculty of Nursing, Beni Suef University, Egypt, (2) Professor of Medical Surgical Nursing, Faculty of Nursing, Ain Shams University, Egypt, (3) Professor of Medical Surgical Nursing, Faculty of Nursing, BenhaUniversity, Egypt and (4) Assistant Professor of Medical Surgical Nursing, Faculty of Nursing, Benha University, Egypt.

\begin{abstract}
Background: Traumatic Head Injury (THI) is a disruption in the normal function of the brain that caused by a blow or jolt to the head. The role of critical care nurses is a vital at the acute care by giving priority of the immediate assessment, stabilization of the airway and circulation and prevention of secondary injury. The aim of this study was to evaluate the effect of an educational program on the nurses' performance and health outcomes for patients with traumatic head injury. Study design: A quasi-experimental design was used. Settings: This study was conducted in the emergency unit and the emergency intensive care unit at Banha University Hospital. Subject: A convenient sample of (50) registered nurses caring for patients with THI and (50) patients with THI were included in the study. Tools: Three tools were used for data collection; I-self-administered questionnaire tool, II- the nurses' practice observational checklist and III-patients' health outcomes assessment. Results: All of the nurses had unsatisfactory knowledge and practice regarding caring for patients with THI pre-program implementation which improved immediately post program implementation (30\% and 24\%), respectively. The mean of the studied patients regarding total trauma scale pre-program implementation was $16.89 \pm 10.61$ that improved immediately post program implementation $13.24 \pm$ 12.08. Conclusion: There was a highly statistical significant improvement in the level of nurses' performance and health outcomes for patients with THI after implementation of the educational program. Recommendations: The importance of continuous in-service training programs about THI for refreshing and updating the nurses' knowledge and practice regarding THI.
\end{abstract}

Keywords: Educational Program, Nurses' Performance, Patients' Health Outcome, Traumatic Head Injury.

\section{Introduction}

Traumatic head injury is an injury that results from a violent blow to the scalp, skull or brain that can result in impaired physical, cognitive, emotional, and behavioral functioning. The severity of THI can range from mild alterations of consciousness to severe comatose state and death (Garcia, 2019).

The most common causes of THI include: falling, violence, sports injuries, vehicle-related collisions, explosive blasts and shaking baby syndrome. The THI is usually classified according to the mechanism of injury into primary and secondary injuries. The primary injuries occur at the moment of initial trauma, while secondary injuries are associated with complications that can arise from primary injuries (Kleinman, 2015).

The goals of emergency medical management include stabilize the patient's condition, maintain adequate cerebral oxygenation, minimize secondary brain injury and complications. The medications that are used to limit secondary damage include: anti- 
seizure drugs, sedation, coma-inducing drugs and osmotherapy (Nedd, 2020).

The critical care nurse has to perform initial assessment and rapid management that they are guided by the ABCDs of the primary survey (Airway, Breathing, Circulation and Disability). It allows early recognition, prioritization and treatment of life-threatening situations. The secondary survey includes Glasgow Coma Scale (GCS), a rapid head-totoe assessment and identifies additional serious injuries throughout the body (Urden et al., 2016).

\section{Significant of the study}

The world health organization estimated that $70 \%-90 \%$ of THI are mild, while $10 \%$ are moderate to severe injuries. The fatality rate is estimated to be $30 \%-50 \%$ ). In Egypt each year, about two million people suffer from THI, about 500,000 patients are hospitalized (Hubbard \& Hodge, 2016). According to the statistics office of Benha University Hospital numbers of patients who hospitalized with mild THI were 1700 patients and about 732 patients with a moderate to severe head injury in 2018.

\section{Aim of the study}

The study aimed to evaluate the effect of an educational program on the nurses' performance and health outcomes for patients with traumatic head injury.

\section{Research Hypothesis:}

There will be a positive improvement in the level of nurses' performance and health outcomes for patients with THI after implementation of the educational program.

\section{Subject and Methods}

\section{Research design:}

A quasi-experimental design was used to achieve the aim of this study.

\section{Setting:}

The study was conducted at Benha University Hospital in the emergency department and the emergency intensive care unit

\section{Subjects:}

- - Convenient sample of nurses (50) who were assigned for caring of patients with THI in the previously mentioned settings.

- - Patients' sample: Includes (50) patients with THI in the above mentioned settings.

\section{Tools of data collection:}

Three tools were constructed and tested by the researcher to collect data pertinent to this study, these tools are:

\section{Tool I): Self-administrated nurses' questionnaire:}

It was used to assess nurses' knowledge for patients with THI. It included two parts as the following:

- Part one: It was concerned with sociodemographic characteristics of the studied nurses as age, sex, marital status, qualifications, general years of experience, years of experience in current unit and previous courses regarding THI.

- Part two: It was concerned with the nurses' knowledge assessment including the following: anatomy and physiology of the brain (9 questions with 9 grades), THI (50 questions with 50 grades) and nurses' role regarding assessment and management for patients with THI (20 questions with 20 grades).

\section{Scoring system:}

The correct answer was given one grade and the incorrect answer was given zero. The total score of knowledge equal $\mathbf{7 9}$ grades and was graded as the following:

- $\quad \geq \mathbf{8 5} \%$ was considered satisfactory level of knowledge ( $\geq 67$ grades).

- $\quad<\mathbf{8 5} \%$ was considered unsatisfactory level of knowledge ( $<67$ grades). 


\section{Tool II): Nurses' practice observational checklist:}

It was used to assess the nurses' practice caring for patients with THI. It consisted of four parts covering the following items: primary assessment of patients' with THI (14 items with14 grades), secondary assessment of patients' with THI (27 items with 27 grades), immediate nursing care of the patients' with THI (11 items with11 grades) and documentation (2 items with 2 grades).

\section{Scoring system:}

Each item was not done by the nurses scored zero and one grade was given for correctly done. The total scores equal $\mathbf{5 4}$ grades. The total score of practice was classified as the following:

- $\quad \geq 85 \%$ was considered satisfactory level of practice ( $\geq 46$ grades).

- $\quad<85 \%$ was considered unsatisfactory level of practice ( $<46$ grades).

\section{Tool III): Patients' health outcomes assessment:}

It was concerned with the health outcomes for patients with THI. It was achieved through the following:

\section{I-Patients' health assessment sheet:}

It included three parts as the following:

- Part one: It was concerned with sociodemographic characteristics of the study subjects' of patients as age, gender, marital status, qualifications, employment status and residence.

- Part two: It was concerned with the patients' medical health history as present medical history (causes of injury, main patients' complain) and past medical history.

- Part three: It was concerned with the clinical data assessment outcomes of the traumatic head patient as vital signs, lab investigation and diagnostic tests.
IIII-Neurological outcome scale for traumatic head injury:

It was concerned with assessment of the neurological outcomes for patients with THI (20 observations). It including the following: level of consciousness ( 3 observations), eye and visual assessment (4 observations), hearing assessment ( 2 observations), facial assessment (2 observations), motor and sensory functions assessment (8 observations) and smell assessment (1 observation).

\section{Scoring system:}

The deterioration of the total neurological health outcomes score decreased with low scores. The total score was classified as the following: -

- Mild with score was ranged from 0 to 17.

- Moderate with score was ranged from 18 to 36.

- $\quad$ Severe with score was ranged from 37 to 47 .

\section{Educational program booklet:}

- It was based on the results obtained from assessment of the nurses' performance and health outcomes for patients with THI before educational program implementation.

- $\quad$ The contents covered the theoretical and practical parts. The theoretical part was concerned with anatomy and physiology of the brain, definition, causes, signs and symptoms, diagnosis, complications, medical treatment of THI and nursing role for patient with THI.

- The practical part content was concerned with the steps for assessment and emergency management for patients with THI. It included the primary assessment, the secondary assessment and an immediate nursing intervention

\section{Ethical consideration:}

The ethical consideration in this study included the following: 
1. The researcher clarified the objective and aim of the study to the subjects included in the study.

2. The researcher assured maintaining privacy for both subjects' data for the purpose of the research only and would not be used for another purpose.

3. Subjects were informed about their rights to participate or withdraw at any time without giving any reason.

\section{Tools validity and reliability:}

\section{- Content validity:}

The tools were revised for content validity by a jury of five experts. All of them were professors of medical surgical nursing at faculty of nursing, Ain Shams University. Required modifications were done.

- $\quad$ Testing reliability of proposed tools was done statistically through Cronbach's Alpha test that was (0.761) for tool I, (0.840) for tool II and (0.782) for tool III.

\section{Pilot study:}

It was carried out on $10 \%$ of nurses and patients (10 nurses and 10 patients) under study to test the applicability, clarity and efficiency of the tools. No modification was done, so the nurses and the patients who shared in the pilot study were included in the sample.

\section{Field of work:}

The aim and nature of the study was explained by the researcher to all subjects who were included in the study and take their oral approval to participate in the study prior to any data collection. The program was implemented for subjects in the previously mentioned settings. The data were included the following phases:

\footnotetext{
- $\quad$ Assessment phase.

- $\quad$ Planning and implementation phase.

- $\quad$ Evaluation phase.
}

\section{Assessment phase (pre-program):}

The researcher assessed the nurses' performance in caring for the patients with THI at Benha University Hospital by using (tools I and II) before developing the educational program. The researcher attended to the setting 3 days per week in the morning and afternoon shifts. The questionnaire was answered by the nurses themselves using (tool I) took about 20-30 minutes. Then, the nurses' practice was observed by the researcher using an observational checklist (tool II) at the time of caring for THI patient prior to implementing the educational program as a baseline data assessment.

\section{Planning and implementation phase:}

- Once the initial assessment finished, the program implementation schedule designed by the researcher and the planned learning activity and media were prepared. At the beginning of the first session, an orientation to the program and the aim of the program were explained to gain their best possible cooperation.

- The program was implemented over 12 weeks. The content of the educational program was divided into 6 sessions. The theoretical part consisted of 4 sessions and the practical part consisted of two sessions. Each session started with a revision of what was given in the previous one and the objective of new topics. The duration of each session about 30 minutes including periods of discussion according to nurses' progress and feedback.

- The booklet was distributed to all nurses in the first day of program implementation.

\section{3- Evaluation phase (post program)}

- After implementation of the educational program, the post test was administered to evaluate the effect of the educational program on the nurses' performance and health outcomes for patient with THI through using the tool I, II and III. 
- The evaluation was done immediately after finishing the sessions by comparing difference between pre and post implementation of the educational program to assess the gain of knowledge and practice.

- $\quad$ The follow-up was done on 24 and 48 hours of patients' admission to evaluate the effect of the educational program on the level of nurses' performance and the patients' health outcomes using tool I, II, and III

\section{Statistical analysis:}

- $\quad$ An IBM compatible personal computer was used to store and analyze data and to produce graphic presentation for some important results. Statistical package for the social science (SPSS) version 22 was used for statistical analysis of data, as it contains the test of significance.

- $\quad$ The data were summarized using 1) the arithmetic mean as an average, describing the central tendency of observation for each variable studied; 2) the standard deviation as a measure of dispersion of results around the mean; and 3) the frequency and percentage of observations for each variable studied with use of Z. Other statistical tests such as $\mathrm{T}$ test correlation coefficient was calculated between socio-demographic data and total knowledge score and between total knowledge score and total practice score. Moreover, CCC and Kappa statistics tests were used to test reliability of the tool.

\section{Results}

Table (1): Represents that $(86 \%)$ of the studied nurses their age ranged between (1830 ) years old, (82\%) of the studied nurses were females, $(60 \%)$ of nurses were married. Regarding educational level (66\%) of the studied nurses had technical nursing education. (60\%) their general years of experience ranged between (1-5) years. (56\%) of the studied nurses were working in emergency intensive care unit. Moreover $(62 \%)$ of the studied nurses their years of experience in current unit ranged between (15 ) years. $(80 \%)$ of the studied nurses were not having sessions about nurses role for patients with traumatic head injury and (12\%) of them were attending training courses.

Table (2): Illustrates that there was high statistical significant difference between nurses' knowledge score regarding traumatic head injury pre and post program implementation with high significant difference $(\mathrm{p} \leq 0.001)$.

Table (3) Illustrates that there was a high statistical significant difference between nurses' total practice score regarding caring of patients with traumatic head injury pre and post program implementation with high significant difference $(\mathrm{p} \leq 0.001)$.

Table (4): Illustrates that $42 \%$ of the studied patients' age ranged between $18<30$ years old, $60 \%$ of the studied patients were males, and $58 \%$ of them were single. Regarding educational level $28 \%$ of the studied patients had diploma education, 56\% of patients were not working and were from rural.

Table (5): Illustrates that $44 \%$ of the studied patients' injury were result from accidents. $80.0 \%$ and $70.0 \%$ respectively of the studied patients their main complain were pain and ecchymosis. $68 \%$ of them were not having chronic disease, $12 \%$ and $10 \%$, respectively of the studied patients were having cardiovascular and respiratory disease.

Table (6): Demonstrates that there was improvement of clinical data of the studied patients post program implementation especially pulse and oxygen saturation.

Table (7): Shows that there was high statistical significant difference of the studied patients' outcomes of regarding LOC, motor and sensory function assessment and total trauma score with highest significance difference $(p \leq 0.05)$. There was statistical significant difference of the studied patients' 
outcomes of regarding eye and visual assessment with significance difference ( $\mathrm{P}$ $\geq 0.05$ ).

Table (8): Represents that there was statistically no significant with positive correlation between patients' outcome and total nurses' knowledge and practice. On the other hands, there was a highly significant positive correlation between nurses' knowledge and their practice pre and post educational program implementation $(\mathrm{r}=$ 0.891).

Table (1): Percentage distribution for the studied nurses according to their demographic characteristics $(\mathbf{n}=\mathbf{5 0})$.

\begin{tabular}{|c|c|c|}
\hline Items & No & $\%$ \\
\hline \multicolumn{3}{|l|}{ Age (years) } \\
\hline $18<30$ & 43 & $86 \%$ \\
\hline $30<40$ & 7 & $14 \%$ \\
\hline \multicolumn{3}{|l|}{ Sex } \\
\hline Male & 9 & $18 \%$ \\
\hline Female & 41 & $82 \%$ \\
\hline \multicolumn{3}{|l|}{ Marital status } \\
\hline Single & 20 & $40 \%$ \\
\hline Married & 30 & $60 \%$ \\
\hline \multicolumn{3}{|l|}{ Educational level } \\
\hline Diploma & 12 & $24 \%$ \\
\hline Technical institute & 33 & $66 \%$ \\
\hline Bachelor degree & 5 & $10 \%$ \\
\hline \multicolumn{3}{|l|}{ Year of experience at work } \\
\hline$<1$ year & 8 & $16 \%$ \\
\hline $1<5$ years & 30 & $60 \%$ \\
\hline $5<10$ years & 11 & $22 \%$ \\
\hline$>10$ years & 1 & $1 \%$ \\
\hline \multicolumn{3}{|l|}{ Workplace } \\
\hline Emergency unit & 22 & $44 \%$ \\
\hline Emergency intensive care unit & 28 & $56 \%$ \\
\hline \multicolumn{3}{|l|}{ Years of experience in this unit } \\
\hline$<1$ year & 12 & $24 \%$ \\
\hline $1<5$ years & 31 & $62 \%$ \\
\hline $5<10$ years & 7 & $14 \%$ \\
\hline \multicolumn{3}{|c|}{$\begin{array}{l}\text { Training courses about nurses role for patients with traumatic head } \\
\text { injury }\end{array}$} \\
\hline Yes & 10 & $20 \%$ \\
\hline No & 40 & $80 \%$ \\
\hline \multicolumn{3}{|l|}{ Mention the type of the course } \\
\hline Training courses & 6 & $12 \%$ \\
\hline Workshops & 4 & $8 \%$ \\
\hline
\end{tabular}


Esraa Hamdy Hassan, Manal Salah Hassan, Hanan Gaber Mohamed, Nehal Mahmoud Abo EL-Fadl

Table (2): Mean, standard deviation and significant difference of the nurses' total knowledge score pre and post educational program implementation $(n=50)$.

\begin{tabular}{|c|c|c|c|c|c|c|c|}
\hline \multirow{2}{*}{ Items } & \multirow{2}{*}{$\begin{array}{l}\text { Total } \\
\text { score }\end{array}$} & \multicolumn{2}{|c|}{ Pre-program } & \multicolumn{2}{|c|}{ Post-program } & \multirow{2}{*}{$\mathbf{T}$} & \multirow{2}{*}{ P-value } \\
\hline & & Mean & SD & Mean & SD & & \\
\hline Anatomy of the brain & 9 & 2.30 & 1.47 & 6.46 & 1.40 & 14.45 & $<0.001 * *$ \\
\hline Definition of THI & 1 & 0.42 & 0.50 & 0.70 & 0.46 & 2.91 & $<0.01 * *$ \\
\hline Causes of THI & 3 & 0.70 & 0.61 & 2.16 & 0.65 & 11.16 & $<0.001 * *$ \\
\hline Classification of THI & 5 & 0.68 & 0.68 & 3.30 & 0.89 & 16.55 & $<0.001 * *$ \\
\hline Signs and symptoms of THI & 9 & 3.00 & 1.37 & 6.24 & 1.56 & 11.04 & $<0.001 * *$ \\
\hline $\begin{array}{l}\text { Diagnostic tests and lab } \\
\text { investigation of THI }\end{array}$ & 7 & 2.20 & 1.20 & 4.54 & 1.18 & 9.84 & $<0.001 * *$ \\
\hline Complications of THI & 14 & 2.66 & 1.75 & 8.08 & 2.46 & 12.72 & $<0.001 * *$ \\
\hline Medical management of THI & 11 & 3.94 & 1.88 & 8.24 & 1.74 & 11.86 & $<0.001 * *$ \\
\hline Emergency nursing care & 20 & 9.90 & 2.56 & 17.76 & 3.03 & 14.01 & $<0.001 * *$ \\
\hline Total knowledge score & 79 & 25.80 & 7.41 & 57.48 & 10.09 & 17.88 & $<0.001 * *$ \\
\hline
\end{tabular}

Statistical significant difference $P \leq 0.05 *$. Highly statistical significant $P \leq 0.001 * *$.

Table (3) Mean, standard deviation and significance difference of the studied nurses according to their total practice score regarding caring of patients with THI $(n=50)$.

\begin{tabular}{|c|c|c|c|c|c|c|c|}
\hline \multirow[b]{2}{*}{ Items } & \multirow[b]{2}{*}{$\begin{array}{l}\text { Total } \\
\text { score }\end{array}$} & \multicolumn{2}{|c|}{ Pre-program } & \multicolumn{2}{|c|}{ Post-program } & \multirow[b]{2}{*}{$\mathbf{T}$} & \multirow[b]{2}{*}{ P-value } \\
\hline & & Mean & SD & Mean & SD & & \\
\hline $\begin{array}{l}\text { The Primary Assessment } \\
(\mathrm{ABCDE})\end{array}$ & 14 & 4.70 & 2.27 & 7.82 & 2.11 & -5.341 & $<0.001 * *$ \\
\hline The Secondary Assessment & 27 & 5.08 & 2.48 & 17.46 & 3.91 & -6.161 & $<0.001 * *$ \\
\hline Immediate Nursing Intervention & 11 & 4.34 & 0.94 & 10.24 & 0.94 & -6.196 & $<0.001 * *$ \\
\hline Documentation & 2 & 0.46 & 0.50 & 0.94 & 0.24 & -4.889 & $<0.001 * *$ \\
\hline Total Practice Scale & 54 & 27.47 & 7.21 & 73.77 & 11.63 & 23.93 & $<0.001 * *$ \\
\hline
\end{tabular}

Statistical significant difference $P \leq 0.05 *$. Highly statistical significant $P \leq 0.001 * *$. 
Effect of an Educational Program on the Nurses' Performance and Health Outcomes for Patients with Traumatic Head Injury

Table (4): Frequency distribution of the studied patients according to their demographic characteristics $(n=50)$.

\begin{tabular}{|c|c|c|}
\hline Items & No & $\%$ \\
\hline \multicolumn{3}{|l|}{ Age } \\
\hline - $18<30$ & 21 & $42.0 \%$ \\
\hline - $30<40$ & 16 & $32.0 \%$ \\
\hline - $40<50$ & 9 & $18.0 \%$ \\
\hline - $50<60$ & 4 & $8.0 \%$ \\
\hline \multicolumn{3}{|l|}{ Gender } \\
\hline - Male & 30 & $60.0 \%$ \\
\hline - Female & 20 & $40.0 \%$ \\
\hline \multicolumn{3}{|l|}{ Marital status } \\
\hline - Single & 29 & $58.0 \%$ \\
\hline - Married & 21 & $42.0 \%$ \\
\hline \multicolumn{3}{|l|}{ Level of education } \\
\hline - Illiterate & 9 & $18.0 \%$ \\
\hline - Basic & 11 & $22.0 \%$ \\
\hline - Diploma & 14 & $28.0 \%$ \\
\hline - Technical institute & 10 & $20.0 \%$ \\
\hline - Bachelor degree & 6 & $12.0 \%$ \\
\hline \multicolumn{3}{|l|}{ Employment status. } \\
\hline - Not Working & 28 & $56.0 \%$ \\
\hline - Working & 22 & $44.0 \%$ \\
\hline \multicolumn{3}{|l|}{ Residence } \\
\hline - Rural & 28 & $56.0 \%$ \\
\hline - Urban & 22 & $44.0 \%$ \\
\hline
\end{tabular}


Table (5): Frequency distribution of the studied patients according to their medical health history $(\mathbf{n}=\mathbf{5 0})$.

\begin{tabular}{|c|c|c|}
\hline $\begin{array}{ll}\text { Items } \\
\end{array}$ & No & $\%$ \\
\hline \multicolumn{3}{|l|}{ 1- Patient's present medical history. } \\
\hline \multicolumn{3}{|l|}{ A- Causes of injury. } \\
\hline$\bullet \quad$ Falls. & 15 & $30.0 \%$ \\
\hline - Accidents. & 22 & $44.0 \%$ \\
\hline - Gun shot. & 1 & $2.0 \%$ \\
\hline - Violence. & 3 & $6.0 \%$ \\
\hline$\bullet \quad$ Sports injury. & 9 & $18.0 \%$ \\
\hline \multicolumn{3}{|l|}{ B- Main patients' complain * } \\
\hline$\bullet \quad$ Pain. & 40 & $80.0 \%$ \\
\hline - Headache. & 16 & $32.0 \%$ \\
\hline - $\quad$ Anorexia. & 1 & $2.0 \%$ \\
\hline - Vomiting. & 15 & $30.0 \%$ \\
\hline - Ecchymosis. & 35 & $70.0 \%$ \\
\hline - Cold skin. & 7 & $14.0 \%$ \\
\hline - Drowsiness. & 4 & $8.0 \%$ \\
\hline \multirow{2}{*}{\multicolumn{3}{|c|}{$\begin{array}{l}\text { 2- Past history. } \\
\text { A-Presence of chronic disease. }\end{array}$}} \\
\hline & & \\
\hline$\bullet \quad \mathrm{No}$ & 34 & $68.0 \%$ \\
\hline - Yes & 16 & $32.0 \%$ \\
\hline \multicolumn{3}{|l|}{ Type of disease. } \\
\hline - Cardiovascular disease. & 6 & $12.0 \%$ \\
\hline - $\quad$ Respiratory disease. & 5 & $10.0 \%$ \\
\hline - $\quad$ GIT disease. & 1 & $2.0 \%$ \\
\hline - Urological disease. & 1 & $2.0 \%$ \\
\hline - Tumors. & 3 & $6.0 \%$ \\
\hline
\end{tabular}

*patient can chose more than one answer

Table (6): Mean, standard deviations and significance difference of the clinical assessment data of the studied patients pre and post educational program implementation $(n=50)$.

\begin{tabular}{|c|c|c|c|c|c|c|c|}
\hline \multirow{2}{*}{ Items } & \multirow[t]{2}{*}{$\mathbf{N}$} & \multicolumn{2}{|c|}{$\begin{array}{c}\text { On admission } \\
\text { (Pre) }\end{array}$} & \multicolumn{2}{|c|}{$\begin{array}{l}\text { After } 24 \text { hrs. } \\
(\text { Post 1) }\end{array}$} & \multicolumn{2}{|c|}{$\begin{array}{l}\text { After 48hrs } \\
\text { (Post 2) }\end{array}$} \\
\hline & & Mean & SD & Mean & SD & Mean & SD \\
\hline \multicolumn{8}{|l|}{ Vital signs. } \\
\hline - Body temperature. & 50 & 36.3 & 0.8 & 36.5 & 0.7 & 36.6 & 0.7 \\
\hline \multicolumn{8}{|l|}{ - $\quad$ Blood pressure. } \\
\hline$\checkmark$ Systolic Blood pressure. & 50 & 115.4 & 18.4 & 114.8 & 15.9 & 115.2 & 14.7 \\
\hline $\begin{array}{ll}\checkmark & \text { Diastolic Blood pressure. }\end{array}$ & 50 & 76.6 & 15.6 & 78.2 & 12.8 & 78.3 & 12.6 \\
\hline - Pulse. & 50 & 66.4 & 9.0 & 69.3 & 7.4 & 70.6 & 7.9 \\
\hline - Respiration. & 50 & 11.8 & 1.5 & 11.9 & 1.3 & 12.2 & 2.2 \\
\hline - Oxygen saturation. & 50 & 90.7 & 5.1 & 95.5 & 2.5 & 95.8 & 2.2 \\
\hline - Central venous pressure. & 13 & 4.8 & 2.0 & 5.0 & 2.0 & 4.9 & 2.0 \\
\hline \multicolumn{8}{|c|}{ Lab investigation and diagnostic tests. } \\
\hline \multicolumn{8}{|l|}{ Arterial blood gases. } \\
\hline • Ph. & 34 & 7.4 & 0.1 & 7.4 & 0.1 & 7.4 & 0.2 \\
\hline - Paco2. & 34 & 39.5 & 9.0 & 36.9 & 7.0 & 36.4 & 6.5 \\
\hline - SPo2. & 34 & 22.8 & 2.1 & 22.8 & 2.7 & 23.0 & 2.7 \\
\hline Blood glucose level. & 50 & 78.1 & 9.5 & 82.3 & 7.9 & 83.4 & 9.1 \\
\hline Intracranial pressure. & 1 & 22.0 & --- & 24.0 & --- & 22.0 & --- \\
\hline
\end{tabular}


Effect of an Educational Program on the Nurses' Performance and Health Outcomes for Patients with Traumatic Head Injury

Table (7) Mean, standard deviations and significant different of the studied patients according to their neurological assessment outcome scale pre and post educational program implementation $(\mathbf{n}=\mathbf{5 0})$.

\begin{tabular}{|l|c|c|c|c|c|c|c|c|c|}
\hline \multirow{2}{*}{ Items } & \multicolumn{2}{|c|}{$\begin{array}{c}\text { On admission } \\
(\mathbf{1})\end{array}$} & \multicolumn{2}{c|}{$\begin{array}{c}\text { After 24 } \\
\text { hours (2) }\end{array}$} & \multicolumn{2}{c|}{$\begin{array}{c}\text { After 48 } \\
\text { hours (3) }\end{array}$} & \multicolumn{4}{c|}{ P-value } \\
\cline { 2 - 11 } & Mean & SD & Mean & SD & Mean & SD & 1 vs 2 & 2 vs 3 & 1 vs 3 \\
\hline $\begin{array}{l}\text { 1- Level of consciousness } \\
\text { (LOC) }\end{array}$ & 4.90 & 2.11 & 3.76 & 2.84 & 3.02 & 3.05 & 0.073 & 0.216 & $\begin{array}{c}< \\
0.001 \\
* *\end{array}$ \\
\hline $\begin{array}{l}\text { 2-Eye and visual } \\
\text { assessment }\end{array}$ & 0.06 & 0.31 & 0.28 & 0.57 & 0.22 & 0.55 & $0.003 *$ & 0.249 & $0.015 *$ \\
\hline 3-Hearing assessment & 1.04 & 1.56 & 1.04 & 1.56 & .96 & 1.56 & 1.000 & 0.471 & 0.471 \\
\hline $\begin{array}{l}\text { 4. facial assessment } \\
\text { 5- Motor and sensory } \\
\text { function assessment }\end{array}$ & 0.00 & 0.00 & 0.00 & 0.00 & 0.00 & 0.00 & $* * *$ & $* * *$ & $* * *$ \\
\hline $\begin{array}{l}\text { 6-Smell assessment } \\
\text { Total Trauma score }\end{array}$ & 10.44 & 7.96 & 9.76 & 8.32 & 8.80 & 8.33 & 0.485 & 0.267 & $\begin{array}{c}0.001 \\
* *\end{array}$ \\
\hline
\end{tabular}

Statistical significant difference $P \leq 0.05^{*}$. Highly statistical significant $P \leq 0.001 * *$.

Table (8): Correlation between studied nurses' total knowledge and practice scores and the patients' health outcomes $(n=50)$.

\begin{tabular}{|l|c|c|c|c|}
\hline \multirow{2}{*}{ Variable } & \multicolumn{2}{|c|}{ Total knowledge score } & \multicolumn{2}{|c|}{ Total practice score } \\
\cline { 2 - 5 } & $\mathbf{R}$ & P-value & R & P-value \\
\hline Patients' health outcome & 0.04 & $\mathrm{P}>0.05$ & 0.11 & $\mathrm{P}>0.05$ \\
\hline Total knowledge score & ------- & ------- & 0.891 & $\mathrm{P}<0.001$ \\
\hline
\end{tabular}

Statistical significant difference $P \leq 0.05 *$. Highly statistical significant difference $P \leq 0.001$

\section{Discussion}

The traumatic head injury is one of the most devastating in human life presents a major worldwide health problem on a person as it can range from complete recovery to permanent disability or death. The critical care nurse must have a set of knowledge and wide base of skills to manage the patient effectively, enhance the patient health outcome and reduce post traumatic disability and mortality (Garcia, 2019).

This study indicated that the majority of nurses were at the age between (18- 30 years). This finding could be explained that in the light of the nature of emergency ICU and emergency department as an area of specialty necessitates a young qualified nurse for better quality of nursing care offered and ability to tolerate the working load. This result is agreed with Maaroof, (2012)", who stated that about two third of the study nurses age were less than thirty years old.

Concerning the educational level, the present study indicated that about two-thirds of nurses were technical institutes that is a leading factor for lack of knowledge and practice regarding caring for patients with THI and which might explain that they are young and tolerate the nature of work in emergency and 
ICU. This finding is supported in a study by Shehab, et al. (2018), who stated that the majority of the nurses who work in intensive were technical institute.

Concerning years of experience, the present study revealed that more than half of the nurses their experience ranged between $(1-$ 5 years) of experience. This could be explained that in light of the nature of the emergency unit, it is as an area of specialty necessitates a young qualified nurse for better quality of nursing care offered and ability to tolerate the working load as patients require complex assessment, highintensity interventions, and continuous nursing vigilance. This finding is supported by Abd ElAziz, (2014) who found that most of nurses were newly graduated and have few years of experience.

Regarding attending training programs, the present study found that the majority of the studied nurses did not attend any courses regarding caring for patients with THI. This may be due to lack of in -service educational programs conducted by administrating staff inside the hospitals. This study finding was supported by Shehab, et al. (2018), who found that all of the study nurses had not attended training courses related to THI.

Concerning the nurses' knowledge, the study finding showed that there was significant statistical improvement in total nurses' knowledge score post-program implementation. This indicates a positive impact of the program on the nurses' knowledge regarding THI. This finding is supported by Seliman, (2015), who stated that there was an improvement in nurses' knowledge score after implementation of the program with high significant statistical difference.

Concerning the nurses' practice, it was found that a highly statistically significant difference in total and subtotal of practice between pre-program and post-program implementation. This indicates a positive impact of the program on the nurses' practice regarding THI. This finding is supported by
Seliman, (2015) who stated that there was an improvement in nurses' practice score after implementation of the program with high significant statistical difference.

The findings of the present study revealed that a third of patients at the aged $(18<30$ years) and more than half of them were males. This indicates that THI is more common in young and adolescent males. This may be due to playing violently, motor vehicle accidents and fire fun injuries, while the housewives stay safe indoor. This agreed with study supported by Abu Nagm, (2016), who conducted study about "Effect of Educational Guidelines on Nurses' performance and Traumatized Patients' Outcome", who found that male patients were higher than female patients as accidents among males more than females and most of patients under the age of thirty.

The findings of the present study revealed that about one-third of studied patients had diploma education. This may be due to increase awareness of our community regarding the importance and necessity of education. This was contraindicated with Abd El-Hay, (2018), who stated that half of the patients under study were illiterate.

The finding of the present study revealed that there was statistical significant improvement of patients' outcomes post program implementation than pre-program implementation. It may be related to positive effect of the educational program on the nurses' performance. This was agreed with Elsaay, (2012) who stated that there was a significant improvement in patient's outcomes post protocol implementation

The current study revealed that there was a positive correlation between nurses' performance and patients' health outcomes. This might due to the positive effect of the training program in the improvement of the nurses' knowledge and practice regarding caring for patients with THI. This result agreed 


\section{Effect of an Educational Program on the Nurses' Performance and Health Outcomes for Patients}

\section{with Traumatic Head Injury}

with Shehab, et al. (2018), who revealed that there were improvements in the patients' postimplementation of the educational program.

\section{Conclusion}

All of the studied nurses had unsatisfactory levels of performance regarding THI pre the program implementation. Meanwhile, the majority of the studied nurses had statistically significant improvement in their performance post-program implementation which supported the study hypothesis. Therefore, there was a highly statistically significant improvement in outcomes of patients under study regarding total trauma score post educational program implementation.

\section{Recommendations}

1. Continuous in-service training programs about THI for refreshing and updating the nurses' knowledge and practice regarding THI.

2. Further researchers recommended implementing the educational training program on a larger sample selected from different geographical areas of Egypt to raise the efficiency of nurses' performance regarding THI

\section{References}

Abd El-Aziz, M.A., (2014). "Effect of Educational Program on Nurses Knowledge and Skill about Oral Care for Traumatized Patients". Doctorate thesis, Faculty of Nursing. Assuit University.

Abd El-Hay, S., (2018). Effect of implementing designed educational training program for neurological nurses on clinical outcomes of stroke patients. Available at: https: //doi.org/10.5430/cns. Volume 6 number 4 p121. Accessed on $9 / 10 / 2020$ at 6 P.M.

Abu Nagm, L.,(2016). Effect of Educational Guidelines on Nurses' performance and Traumatized Patients' Outcome. Published doctorate thesis, faculty of nursing. Cairo University.

Elsaay, H. (2012)."'Impact of Implementing Nursing Care Protocol on Moderate Head Injured Patients Outcome" Master thesis, Faculty of Nursing. Tanta University.

Garcia, C. (2019)."Traumatic Brain Injury: Assessment and Management" $1^{\text {st }}$ ed. Hayle Medical, New York. Pp150-184.

Hubbard, J. and Hodge, S. (2016). "Head Trauma and Brain Injury for Lawyers". $1^{\text {st }}$ ed. American Bar Association, USA. Pp 250-270.

Kleinman, P., (2015). Diagnostic imaging of child abuse, $3^{\text {rd }}$ ed., Cambridge University press, England. Pp. 268-275.

Maaroof, D. (2012). "Nurses' Performance for Patients with Traumatic Head Injury in Golden Hour". Published Master Thesis, Faculty of Nursing. Ain Shams University.

Nedd, K., (2020). Traumatic brain injury from head to tail, $1^{\text {st }}$ ed., Archway publishing, USA. Pp. 150-173.

Seliman, A.M. (2015):"'Impact of a Designed Head Trauma Nursing Management Protocol on Critical Care Nurses' Knowledge and Practices at Emergency Hospital Mansoura University". Doctorate thesis, Faculty of Nursing. Mansoura University.

Shehab, M.S., Ibrahim, N.M. and Abd-EI Kader, H. (2018). "Impact of an Educational Program on Nurses' Knowledge and Practice Regarding Care of Traumatic Brain İnjury Patients at Intensive Care Unit at Suez Canal University Hospital", PHD thesis, Faculty of Nursing, Port Said University.

The statistics office of Benha University Hospital

Urden, L.D., Stacy, K.M. and Lough, M.E. (2016). Cardiovascular Clinical Assessment and Diagnostic Procedures. Priorities in Critical Care Nursing. $7^{\text {th }}$ ed. Edited by the same authors. Elsevier Inc. Canada. P. 144. 
تأثير برنامج تعليمي على أداء الممرضات والنتائج الصحية للمرضى الذين يعانون من إصابات في الرأس إسر اء حمدي حسن علي - منال صلاح حسن - حنان جابر محمد - نهال محمود أبو الفضل

تعتبر إصابات الر أس اضطر اب في الوظيفة الطبيعية للاماغ ناتج عن ضربة أو هزة في الر أس. تلعب ممرضات

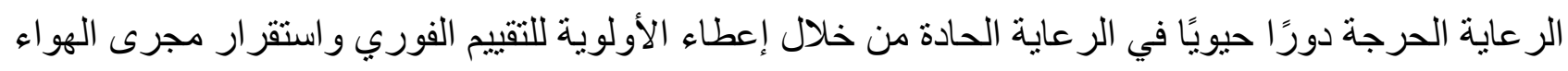

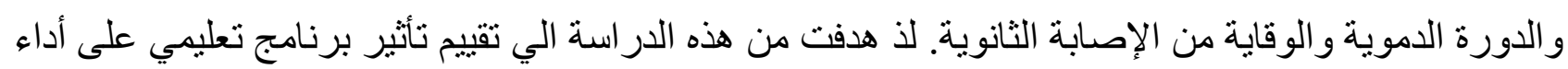

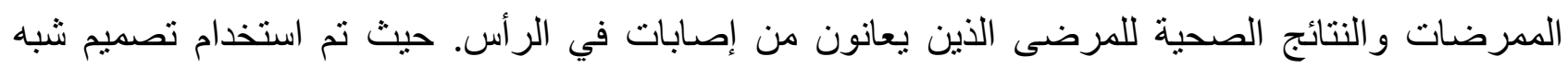

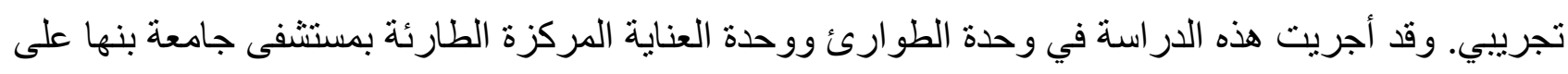
عينة مناسبة من (•0) ممرضة مسجلة ترعى مرضى إصابات الرأس و ( •0) مريضا مع إصابات الرأس نم

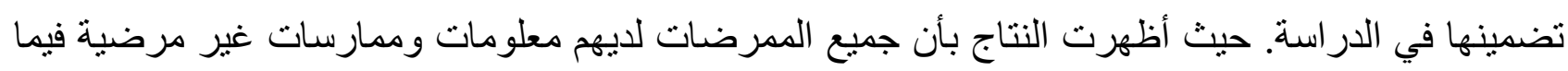

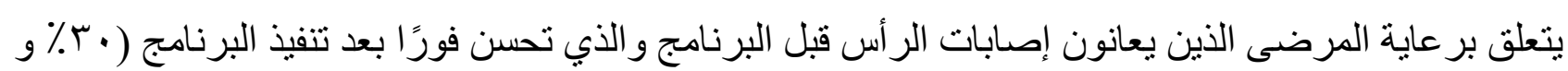
ع ؟r\%) على التو الي. حيث خلصت بوجود تحسن ذو دلالة إحصائية عالية في مستوى أداء الممرضات والنتائج

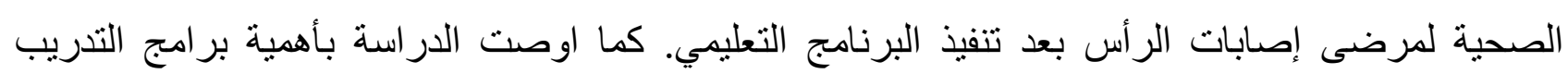

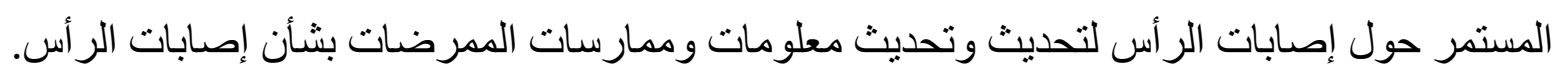

